\title{
Formation and Training of Peer Counselors on PKPR and Post-Covid-19 AKB Socialization
}

\author{
Sri Susilawati*, Winda Windiyani, Dewi Nurdianti, Ade Kurniawati \\ Prodi DIII Kebidanan Fakultas IImu Kesehatan Universitas Muhammadiyah Tasikmalaya \\ *Corresponding Author: susilawati.sri88@gmail.com
}

\section{A bstrak}

Limited knowledge of students about adolescent reproductive health is a problem that is often found in Islamic boarding school. The behavior of teenagers who often wear clothes or towels alternating with friends will be very influential for the reproductive health of adolescents, and it is feared that it could become a medium of spread of covid-19. Therefore, it is necessary to establish youth counselors and training through the provision of information as well as counseling practices on Youth Care Health Services (PKPR) and Socialization of New Habit Adaptation (AKB) after covid-19 in Al-Ittihaad Islamic Boarding School Purbaratu. The purpose of this PKM activity is to train and provide information on the importance of maintaining health by paying attention to adolescent reproductive health behaviors in Islamic boarding school with the implementation of health protocols / adaptation of new habits (AKB), which in the end participants are able to relay the information that has been obtained during the training process to others. The method in this activity is the establishment of youth counselors from santri sons and daughters. Providing training by directly training participants conduct counseling practices to their peers in the post-covid-19 PKPR and AKB. Conduct health protocols to prevent the spread of covid-19 virus in Islamic boarding school. The result of this activity is the increasing knowledge and skills of peer counsellors about PKPR and AKB post-covid-19 in Islamic boarding school.Conclusion is that participants can know and better understand and apply directly the material about PKPR and AKB post-covid-19 in Islamic boarding school.
\end{abstract}

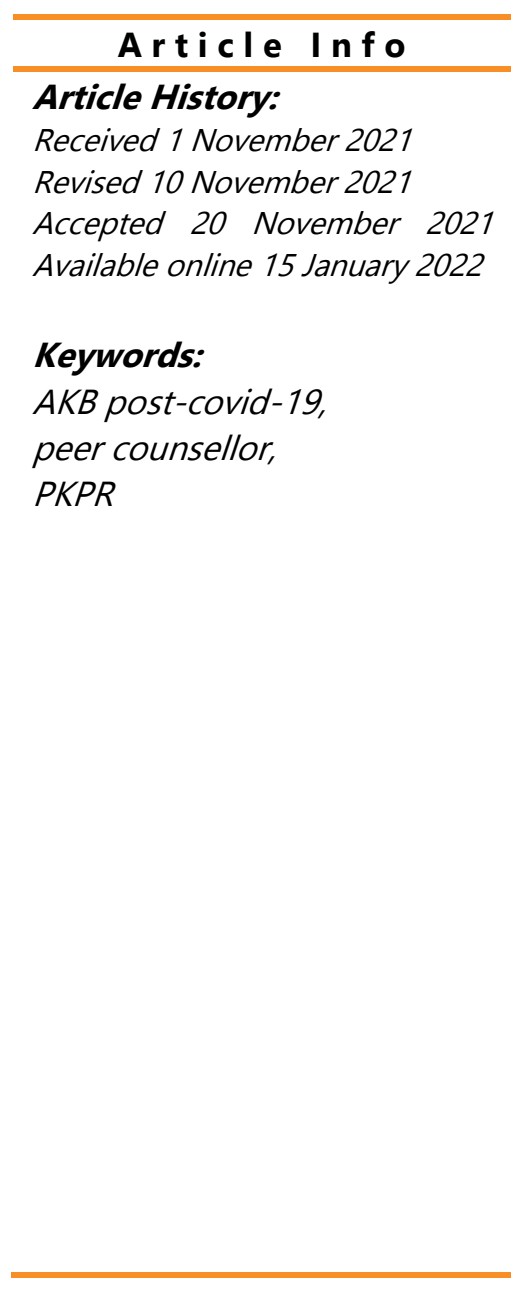

\section{INTRODUCTION}

According to $\mathrm{WHO}$, adolescents are residents in the age range of 10-19 years, according to the Regulation of the Minister of Health of the Republic of Indonesia Number 25 of 2014 adolescents are residents in the age range of 10-18 years and according to the Population and Family Planning Agency (BKKBN) the age range of adolescents is 10-24 years. and unmarried (Diananda, 2019). During this period, adolescents experience many physical, hormonal and psychosocial changes. They often feel uncomfortable and react emotionally, for example irritable, easily angry, like to argue, no longer want to be considered as children, but cannot be given full responsibility as adults (Directorate of Child Health Development, 2016).

Adolescent mental health is closely related to self-concept, which is formed from the experience of adolescents in solving problems. With good mental health will form a strong adolescent character to the problems of life in the future. Adolescents experience problems that can hinder their psychological growth and development and contribute to the formation of their 
self-concept, so that there is a risk of adolescent self-confidence to face the future. Based on the results of community service activities (Novianti, 2020) it was found that there was an increase in the ability to find good friends, recognize problems that might arise in friendship and how to speak assertively. (Novianti \& Tobing, 2020)

Islamic boarding schools are one form of community activity in the religious path that plays an important role in the development of human resources. Poskestren (Pesantren Health Center) is a form of community empowerment in Islamic boarding schools which is a facilitation effort, with the aim that the residents of Islamic boarding schools know and understand the health problems they face, and are expected to plan and make efforts to solve them by utilizing the potential according to the situation, conditions and conditions. the needs of the boarding school. (Nadrati et al., 2019)

In connection with the Adaptasi Kebiasaan Baru (AKB) post-covid-19, it is considered necessary for the author to carry out socialization regarding this which aims to provide protection for the activities of Kiayi, Santri and Asatidz in Islamic boarding schools in the context of preventing and controlling Coronavirus Disease 2019 ( Covid-19) during the pandemic.

The training program is carried out through activities inside and outside the Islamic boarding school, while the mentoring program is carried out directly in the form of practice in the field by staff from the nearest Puskesmas. The trainer acts as a material provider and mentor during discussions and practice. Submission of material using the lecture method is carried out in Islamic boarding schools followed by discussions and practices carried out directly by the training participants under the guidance of the trainer. (Khalid, 2012)

In addition to training or counseling activities, this activity also initiates the formation of Peer Counselors. Peer counselors have roles, including helping to socialize the role and function of counseling guidance, increasing self-competence (positive personality) to be able to become counselors, helping solve peer problems through counseling activities. (Wulandari \& Virahani, 2020)

The problem that is often encountered in Islamic boarding schools, especially at the AlIttihaad Islamic Boarding School Sukajaya Purbaratu, is the limited knowledge about adolescent reproductive health of students in Islamic boarding schools. This ignorance stems from limited information about knowledge about adolescent reproductive health. Another obstacle is related to the behavior of teenage students who often wear clothes or towels alternately with friends and there are still many poor boarding schools environmental sanitation, so these things will greatly affect the reproductive health of adolescents, and it is feared that they could be a medium for the spread of COVID-19.

The purpose of this activity is to provide assistance and guidance related to Youth Care Health Services (PKPR) for Peer Counselors at Al-Ittihaad Islamic Boarding School Purbaratu. The selection of mentoring for peer counselors, both male and female, is motivated by the fact that they are the ones who have the task and are responsible for various activities related to the health of the santri in the Islamic boarding school. This training is also practiced directly by peer counselors, so that the skills of peer counselors can directly provide counseling to teenage students, both male and female, and can also directly apply the socialization of new post-covid19 adaptation of activities (AKB)in Islamic boarding schools.

\section{METHOD}

This service activity is a community partnership program carried out at the Al-Ittihaad Purbaratu Islamic boarding school on November 4-5, 2020. The population is all students at the Islamic boarding school and a sample of 10 female students and 10 male students is taken randomly. 
This community service activity is carried out with the preparation stage, implementation of activities, evaluation, reporting stage and making scientific articles. Starting with the preparation stage by giving permission to carry out activities to the leadership where the activities are carried out, division of service team tasks, forming peer counselors, and preparing materials and modules that will be delivered to training participants. The next stage is the implementation of activities by providing information and education to training participants regarding Youth Care Health Services (PKPR) and Post-Covid-19 New Habit Adaptation Socialization in Islamic Boarding Schools, with the method used is interactive discussion where training participants conduct peer counseling regarding PKPR and AKB post-covid-19 in Islamic boarding schools. The next stage is evaluation, namely by monitoring and assessing the progress of the trainees by paying attention to the ability of participants in their role as peer counselors during the counseling process to their peers. The output targets in this service activity are increasing the knowledge, understanding and skills of participants regarding Youth Care Health Services (PKPR) and Post-Covid-19 New Habit Adaptation Socialization in Islamic Boarding Schools, and changes in the behavior of students in Islamic boarding schools after counseling.

\section{RESULT}

The series of activities that have been carried out include on November 4, 2020 the formation of peer counselors for male and female students with the selection of peer counselors from representatives of the entire number of students in the pesantren. The activity begins with an explanation of the formation of peer counselors and their duties, distribution of training kits containing training modules that participants must learn. This activity also provides a question and answer session with partners if there is anything that needs to be discussed. This activity ended with a presentation during the meeting process not to forget to implement health protocols, namely wearing masks, washing hands, and maintaining distance.

Activities with partners were carried out again on November 5, 2020, still in the Al-Ittihaad Purbaratu Islamic Boarding School hall. The event started with ice breaking to increase the spirit of the participants' training. Followed by the delivery of information and education regarding Healthy Life Skills Education (PKHS) and Post-Covid-19 New Habit Adaptation Socialization at Islamic Boarding Schools. In the middle of the event, the material delivery was interspersed with a question and answer discussion, and an evaluation of the extent to which the participants could understand the training material presented.

\section{DISCUSSION}

The consistency of partners in participating in this activity from the beginning to the end of the series of events is an indicator of the success of this service program. In addition, the training participants paid close attention and concentrated, understood the contents of the training module, were able to answer all questions from the training presenters, and were skilled in providing counseling to peers regarding PKPR and AKB post-covid-19. There are no obstacles encountered in this community service activity.

Some research results target life skills education for teenagers as one of the important tools to build adolescent character. On average, it can be seen in people's lives that today's youth tend to be unprepared and not equipped with life skills. Finally, there have been various declines in the quality and quantity of troubled youth. (Tri Ermayani, 2015). This is in accordance with the agenda for service activities that have been carried out by the team to equip participants with life skills, namely the Youth Care Health Service (PKPR), which includes healthy life skills by paying attention to ten psychosocial competencies that have an impact on the 
development of adolescent behavior, namely: self-awareness, empathy, decision making, problem solving, critical thinking, creative thinking, effective communication, interpersonal relationships, emotional control, and coping with stress. Adolescents who are included in the young population are development capital, namely as factors of production of human labor, if they can be used properly and well on condition that they have the expertise, skills and opportunities to work. However, if the teenager is not in prime condition, the opposite will happen. (Berdian Tamza, 2013).

\section{CONCLUSIONS AND SUGGESTIONS}

This community service activity has provided a lot of information and education as well as counseling skills to the trainees, so that their knowledge and skills as well as soft skills have increased. Peer counselors / healthy santri cadres need to find more creative ways to convey information or messages that have been learned and practiced during the training, so that peers and boarding school residents better understand what has been conveyed, taking into account the educational level of the target group that we invite. communication/consulting.

\section{ACKNOWLEDGMENTS}

The service team thanked the Institute for Research and Community Service (LPPM) Universitas Muhammadiyah Tasikmalaya for the provision of community service funds charged in the 2020 fiscal year. The service team also thanked the leadership of the Al-Ittihaad Purbaratu Islamic Boarding School for being willing to become partners in this community service. The service team also expressed their gratitude for the opportunity to the Head of the Purbaratu Health Center, the Coordinator Midwife, and the UKS Section of the Purbaratu Health Center at the beginning of the field survey for providing direction and permission in the form of a community service partner letter.

\section{REFERENCES}

Berdian Tamza, R. (2013). Hubungan Faktor Lingkungan Dan Perilaku Dengan Kejadian Demam Berdarah Dengue (Dbd) Di Wilayah Kelurahan Perumnas Way Halim Kota Bandar Lampung. Jurnal Kesehatan Masyarakat Universitas Diponegoro, 2(2), 66-73.

Diananda, A. (2019). Psikologi Remaja Dan Permasalahannya. Journal ISTIGHNA, 1(1), 116-133. https://doi.org/10.33853/istighna.v1i1.20

Direktorat Bina Kesehatan Anak. (2016). MODUL PELATIHAN PKPR BAGI KONSELOR SEBAYA.pdf. Khalid, A. (2012). Promosi Kesehatan dengan Pendekatan Teori zperilaku Media dan Aplikasinya. Rajawali Pers.

Nadrati, B., Wijayanto, W. P., \& Musniati, M. (2019). Gambaran Perilaku Hidup Bersih Dan Sehat (Phbs) Santri Di Pondok Pesantren Ad Diinul Qoyyim Lombok Barat. Holistik Jurnal Kesehatan, 13(1), 1-6. https://doi.org/10.33024/hjk.v13i1.1126

Novianti, E., \& Tobing, D. L. (2020). Pemberdayaan Kelompok Remaja dalam Pencegahan Perilaku Bullying di SMA X Baros Serang Banten. ABDIMAS: Jurnal Pengabdian Masyarakat, 3(2), 236-246. https://doi.org/10.35568/abdimas.v3i2.458

Tri Ermayani. (2015). Juvenile character building through life skills. 127-141.

Wulandari, D., \& Virahani, A. (2020). Gambaran Pondok Pesantrean berbasis Poskestren di Kabupaten Semarang. Pro Health Jurnal IImiah Kesehatan, 2(1), 35-39. https://doi.org/10.35473/proheallth.v2i1.387 


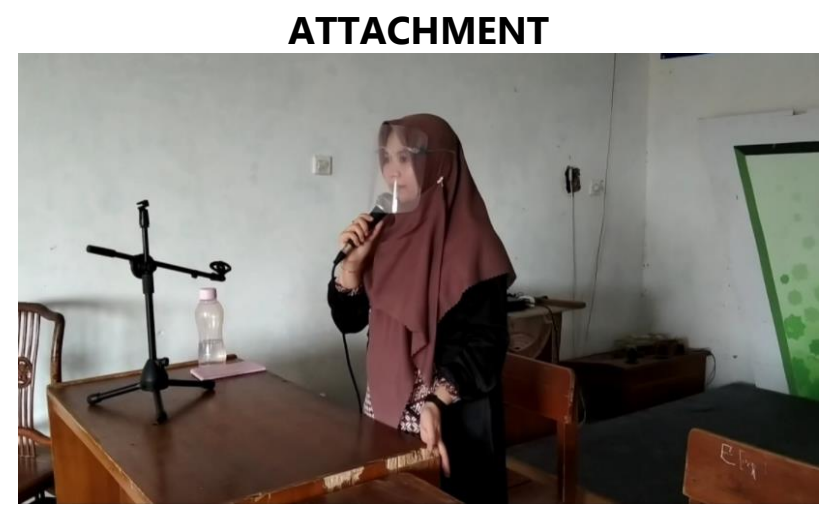

Figure 1. Formation of peer counselors for male and female students Source: 2020 Team Documentation

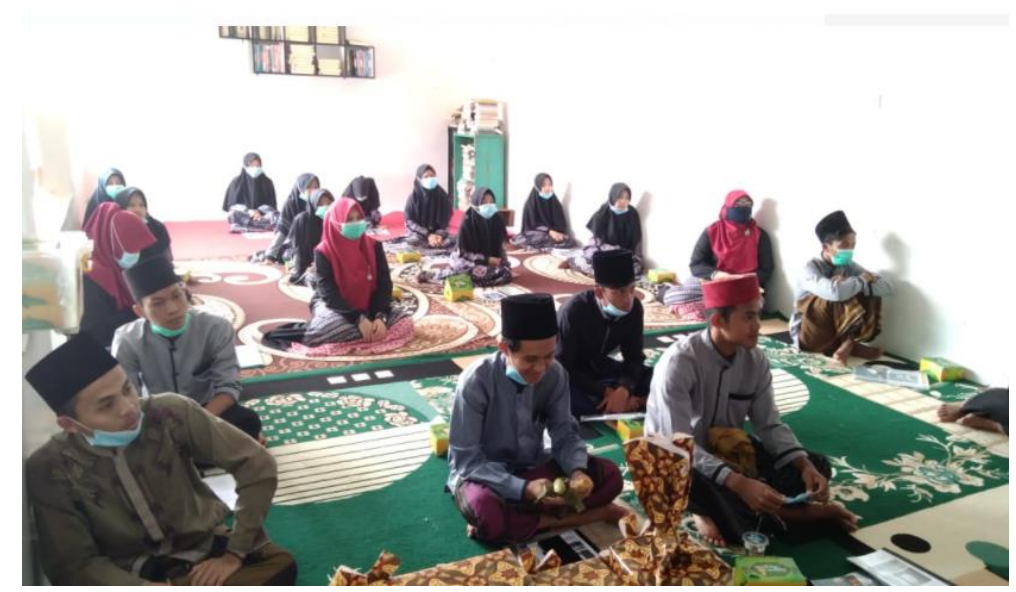

Figure 2. Peer Counselor Training on PKPR and Post-Covid-19 IMR Socialization Source: 2020 Team Documentation

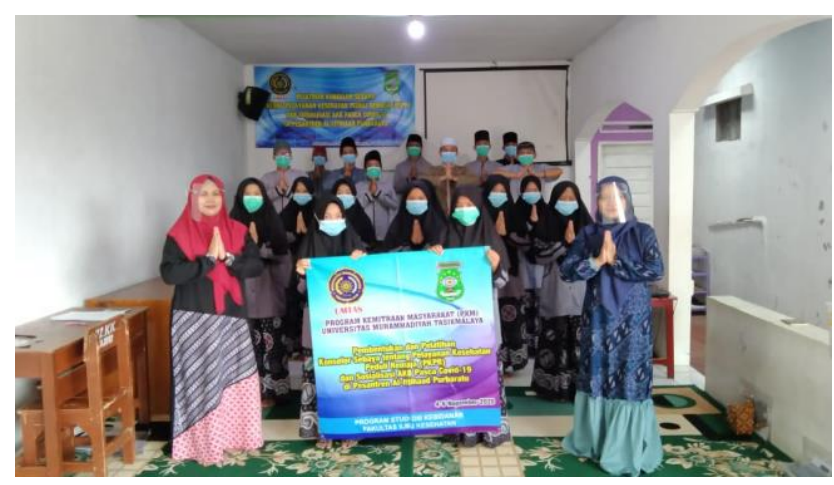

Gambar 3. Peer Counselors for male and female students after training Source: 2020 Team Documentation 